\title{
The Spatial Dimension Of Take-Offs And Sustainability: The Case Of East Asian Countries
}

Paul Moon Sub Choi, Ewha Womans University, Republic of Korea Jinhwan Oh, Ewha Womans University, Republic of Korea Changsu Ko, University of California, Los Angeles, USA

\begin{abstract}
This study examines the relationship between the size of a country and its "take-off" for economic development. We find that most countries which experienced economic upheavals in the past decades are relatively small in terms of area. Specifically, take-offs appear to be quicker for smaller landmasses with larger potential workforce and higher population density, controlled for financial markets maturity, corporate governance, economic openness, and human capital development. We also find that take-offs are not sustainable by nature as most countries in East Asia that which experience take-offs are currently facing slow-downs of their economies. Through this finding, we predict that China may experience a slow-down at around 36\% and may reach to the 50-60\% of income level of the U.S.
\end{abstract}

Keywords: Economic Development; Spatial Development Factors; Corporate Governance; Economic Openness; Human Capital

\section{INTRODUCTION}

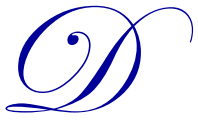

evelopment processes are heterogeneous across countries and regions (Table 1). Some have continuously been in the stage of developed countries for more than half a century (e.g. Western Europe, the U.S. and Canada), while some have risen rapidly during the past decades (e.g. four East Asian "tigers," such as Korea, Taiwan, Hong Kong, and Singapore). On the other hand, some countries have been left behind from the developed club (e.g. Argentina and Uruguay), while others have been caught in the poverty trap and have never experienced growth (e.g. Sub-Saharan African countries). In 1955, there were 18 countries whose per capita incomes were more than $50 \%$ of the U.S., and 15 of them are currently still maintaining their stata (Penn World Table 6.1). ${ }^{1}$ In comparison, 29 countries whose per capita income is more than $50 \%$ of the U.S. in 2007 have joined this club between 1970 and 2000.

What makes these countries different from each other? How come some countries have shown rapid developments while others have not? Recently, geographical explanations for the process of economic development have drawn attention. Krugman $(1991,1998)$ argues that development is made in the interaction between centrifugal and centripetal forces in the core and periphery, thus making geography play a vital role in economic development. World Bank's World Development Report (2009) puts emphasis on spatial policies (spatially blind, connective, and targeted) in each stage of incipient, intermediate, and advanced urbanization, and argues that successful urbanization and economic development can be achieved by "reshaping" the economic geography.

This study starts from geographical perspectives. In particular, this paper investigates the size of a country as a determinant for its take-off. There has been a group of articles in the literature that used the population of a country as a development factor: Milner and Westaway (1993), Briguglio (1995), Alesina and Spolaore (1997), Alesina and Wacziarg (1998), Armstrong and Read (1998), Briguglio (1998), and Easterly and Kraay (2000). In addition to population, we employed the actual geographical size (land area) of a country, and investigated whether small-sized is a necessary or sufficient condition for economic development.

${ }^{1}$ See Table 7, Appendix A, for a summary. 
Table 1. List of countries whose per capita income is above $50 \%$ of that of the U.S.

KOR (South Korea), CYP (Cyprus), TWN (Taiwan), BHS (Bahamas), PRI (Puerto Rico), GRC (Greece, JPN (Japan), GER (Germany), ESP (Spain), CHL (Chile), IRL (Ireland), HKG (Hong Kong, ARE (United Arab Emirates), BMU (Bermuda), BRN (Brunei), KWT (Kuwait), MAC (Macao), QAT (Qatar), SGP (Singapore), ISR (Israel), BRB (Barbados), NZL (New Zealand), ITA (Italy), FRA (France), FIN (Finland), SWE (Sweden), DNK (Denmark), BEL (Belgium), NLD (Netherlands), AUT (Austria), AUS (Australia, CAN (Canada, ISL (Iceland), LUZ (Luxenburg), NOR (Norway), USA (United States).

\begin{tabular}{|c|c|c|c|c|c|c|c|c|c|c|c|c|}
\hline Year & 1955 & 1960 & 1965 & 1970 & 1975 & 1980 & 1985 & 1990 & 1995 & 2000 & 2005 & 2007 \\
\hline No. of countries & 18 & 19 & 19 & 22 & 34 & 39 & 37 & 35 & 38 & 36 & 41 & 44 \\
\hline \multirow[t]{50}{*}{ Country } & ARG & ARG & $\mathrm{ARG}$ & ARG & $\mathrm{ARG}$ & $\mathrm{ARG}$ & $*$ & $*$ & $*$ & $*$ & $*$ & $*$ \\
\hline & AUS & AUS & AUS & AUS & AUS & AUS & AUS & AUS & AUS & AUS & AUS & AUS \\
\hline & AUT & AUT & AUT & AUT & AUT & AUT & AUT & AUT & AUT & AUT & AUT & AUT \\
\hline & BEL & BEL & BEL & BEL & BEL & BEL & BEL & BEL & BEL & BEL & BEL & BEL \\
\hline & CAN & CAN & CAN & CAN & CAN & CAN & CAN & CAN & CAN & CAN & CAN & CAN \\
\hline & $\mathrm{CHE}$ & CHE & $\mathrm{CHE}$ & CHE & $\mathrm{CHE}$ & $\mathrm{CHE}$ & $\mathrm{CHE}$ & CHE & $\mathrm{CHE}$ & $\mathrm{CHE}$ & $\mathrm{CHE}$ & CHE \\
\hline & DNK & DNK & DNK & DNK & DNK & DNK & DNK & DNK & DNK & DNK & DNK & DNK \\
\hline & FIN & FIN & FIN & FIN & FIN & FIN & FIN & FIN & FIN & FIN & FIN & FIN \\
\hline & FRA & FRA & FRA & FRA & FRA & FRA & FRA & FRA & FRA & FRA & FRA & FRA \\
\hline & GBR & GBR & GBR & GBR & GBR & GBR & GBR & GBR & GBR & GBR & GBR & GBR \\
\hline & ISL & ISL & ISL & ISL & ISL & ISL & ISL & ISL & ISL & ISL & ISL & ISL \\
\hline & LUX & LUX & LUX & LUX & LUX & LUX & LUX & LUX & LUX & LUX & LUX & LUX \\
\hline & NLD & NLD & NLD & NLD & NLD & NLD & NLD & NLD & NLD & NLD & NLD & NLD \\
\hline & NOR & NOR & NOR & NOR & NOR & NOR & NOR & NOR & NOR & NOR & NOR & NOR \\
\hline & NZL & NZL & NZL & NZL & NZL & NZL & NZL & NZL & NZL & NZL & NZL & NZL \\
\hline & SWE & SWE & SWE & SWE & SWE & SWE & SWE & SWE & SWE & SWE & SWE & SWE \\
\hline & URY & $*$ & $*$ & $*$ & $*$ & $*$ & $*$ & $*$ & $*$ & $*$ & $*$ & $*$ \\
\hline & VEN & VEN & $*$ & $*$ & $*$ & $*$ & $*$ & $*$ & $*$ & $*$ & $*$ & $*$ \\
\hline & & ISR & ISR & ISR & ISR & ISR & ISR & ISR & ISR & ISR & ISR & ISR \\
\hline & & ITA & ITA & ITA & ITA & ITA & ITA & ITA & ITA & ITA & ITA & ITA \\
\hline & & & BRB & BRB & BRB & BRB & BRB & BRB & BRB & BRB & BRB & BRB \\
\hline & & & & ESP & ESP & ESP & ESP & ESP & ESP & ESP & ESP & ESP \\
\hline & & & & GRC & GRC & GRC & GRC & GRC & GRC & GRC & GRC & GRC \\
\hline & & & & JPN & JPN & JPN & JPN & JPN & JPN & JPN & JPN & JPN \\
\hline & & & & & ARE & ARE & ARE & ARE & ARE & ARE & ARE & ARE \\
\hline & & & & & BHR & BHR & BHR & BHR & BHR & $*$ & BHR & BHR \\
\hline & & & & & BMU & BMU & BMU & BMU & BMU & BMU & BMU & BMU \\
\hline & & & & & BRN & BRN & BRN & BRN & BRN & BRN & BRN & BRN \\
\hline & & & & & GER & GER & GER & GER & GER & GER & GER & GER \\
\hline & & & & & IRL & IRL & IRL & IRL & IRL & IRL & IRL & IRL \\
\hline & & & & & KWT & KWT & KWT & KWT & KWT & KWT & KWT & KWT \\
\hline & & & & & LBY & LBY & LBY & $*$ & $*$ & $*$ & $*$ & LBY \\
\hline & & & & & PLW & PLW & PLW & PLW & $*$ & $*$ & $*$ & $*$ \\
\hline & & & & & QAT & QAT & QAT & QAT & QAT & QAT & QAT & QAT \\
\hline & & & & & SAU & SAU & SAU & SAU & $*$ & $*$ & $*$ & $*$ \\
\hline & & & & & TTO & TTO & $*$ & $*$ & $*$ & $*$ & TTO & TTO \\
\hline & & & & & & BHS & BHS & BHS & BHS & BHS & BHS & BHS \\
\hline & & & & & & HKG & HKG & $\mathrm{HKG}$ & $\mathrm{HKG}$ & HKG & HKG & HKG \\
\hline & & & & & & MAC & MAC & MAC & MAC & MAC & MAC & MAC \\
\hline & & & & & & $\mathrm{OMN}$ & OMN & $*$ & $*$ & $*$ & OMN & OMN \\
\hline & & & & & & SGP & SGP & SGP & SGP & SGP & SGP & SGP \\
\hline & & & & & & & & & CYP & CYP & CYP & CYP \\
\hline & & & & & & & & & KOR & $*$ & KOR & KOR \\
\hline & & & & & & & & & PRI & PRI & PRI & PRI \\
\hline & & & & & & & & & TWN & TWN & TWN & TWN \\
\hline & & & & & & & & & & & GNQ & $*$ \\
\hline & & & & & & & & & & & SVN & SVN \\
\hline & & & & & & & & & & & & BLR \\
\hline & & & & & & & & & & & & CZE \\
\hline & & & & & & & & & & & & MLT \\
\hline
\end{tabular}

Source: Penn World Table 6.1 
We argue that small countries (in terms of land area and population) are not necessarily efficient in taking off. However, most countries that experienced the "take-off" and have been "flying" for the past decades were relatively small. We will examine this by conducting panel regrssions. For robustness tests, we consider several control variables that may also affect development. La Porta et al. (1998) and Djankov et al. (2008) argue that the degrees of financial investor protection and governance enforcement are strongly and positively correlated with sustainable economic development. Lucas (2009) claims that open countries perform better in economic growth. In addition, Eichengreen et al. (2013) find that countries with highly educated people are advantageous in economic growth. In this research, the empirical implication is that an average economy grows faster the smaller the landmass, and/or the larger the potential workforce, and/or the higher the population density, controlled for the quality indices of capital markets, economic regime, openness, and human capital.

However, take-off is not sustainable by nature and an economy may slow-down after a certain period of rapid growth regardless of its size. In this aspect, his study also examines a non-linear relationship between income levels and growth rates. Japan, South Korea and Taiwan are paid extra attendtions, as they all went through successful take-offs and are good fits of the model that we suggest. Lessons of these countries are applied to China which is now undergoing a take-off to see when the economy is expected to slow-down.

This paper is organized as follows: Section 2 provides data description; Section 3 examines spatial factors that determine the take-off of an economy, controlled for other variables. Section 4 investigates the sustainability of take-off by examing a non-linear relationship between income levels and growth rates. Section 5 concludes the study.

\section{DATA}

We source Penn World Table 6.1 for the per capita of real GDPs of 190 countries relative to the U.S. between 1950 and 2007. Except for the year of 1950 when there were substantial missing values, we referred to the countries whose income is above $50 \%$ of that of the U.S. as relatively rich or developed ones (Tables 1 and 7 ). This is a key variable in this study, as it will be used as a dependent variable in examining the determinants for take-off and as an explanatory variable in examining its sustainability.

There are 17 countries that were listed, and these countries are named the "old-rich", and summarized as Group 2 in Table 2. More importantly, there are 19 countries that were not listed in 1955, but later on listed in 2007. To confirm that our selection for countries have sustainable growths, this paper has outlined the following rules. Countries that satisfy these rules are named "take-offs", and listed as Group 1 in Table 2. For 148 countries in Group 3, the average area is 683,879 square kilometers, average population is 34.2 million, and average density is 296 . 
For 148 countries in Group 3, average area is 683,879 (sq. km), average population is 34,228 ('000s), and average density is 296.

Table 2. Descriptive statistics of countries in each group

\begin{tabular}{|c|c|c|c|c|c|c|c|}
\hline $\begin{array}{c}\text { Group } 1 \\
\text { (19 take-offs) }\end{array}$ & $\begin{array}{c}\text { Land Area } \\
(\mathrm{sq} \cdot \mathrm{km})\end{array}$ & $\begin{array}{l}\text { Population } \\
(2005, ' 000 s)\end{array}$ & $\begin{array}{c}\text { Population } \\
\text { density (2005) }\end{array}$ & $\begin{array}{c}\text { Group } 2 \\
\text { (17 old riches) }\end{array}$ & $\begin{array}{c}\text { Land Area } \\
(\mathrm{sq} \cdot \mathrm{km})\end{array}$ & $\begin{array}{l}\text { Population } \\
(2005, \text { '000s })\end{array}$ & $\begin{array}{c}\text { Population } \\
\text { density (2005) }\end{array}$ \\
\hline Bahamas & 10,070 & 325 & 23 & Australia & $7,617,930$ & 20,395 & 3 \\
\hline Bermuda & 53 & 64 & 1,211 & Austria & 82,444 & 8,232 & 98 \\
\hline Brunei & 5,270 & 370 & 64 & Barbados & 431 & 253 & 589 \\
\hline Chile & 748,800 & 16,297 & 22 & Belgium & 30,278 & 10,415 & 341 \\
\hline Cyprus & 9,240 & 836 & 90 & Canada & $9,093,507$ & 32,307 & 3 \\
\hline Germany & 349,223 & 82,409 & 231 & Denmark & 42,394 & 5,417 & 126 \\
\hline Greece & 130,800 & 11,064 & 84 & Finland & 304,473 & 5,244 & 16 \\
\hline Hong Kong & 1,042 & 6,883 & 6,263 & France & 640,053 & 61,013 & 111 \\
\hline Ireland & 68,890 & 4,187 & 60 & Iceland & 100,250 & 296 & 3 \\
\hline Japan & 374,744 & 127,449 & 337 & Israel & 20,330 & 6,692 & 302 \\
\hline South Korea & 98,190 & 47,566 & 478 & Italy & 294,020 & 58,645 & 195 \\
\hline Kuwait & 17,820 & 2,700 & 152 & Luxembourg & 2,586 & 464 & 179 \\
\hline Macao & 28 & 488 & 18,755 & Netherlands & 33,883 & 16,316 & 393 \\
\hline Puerto Rico & 8,870 & 3,913 & 441 & New Zealand & 268,021 & 4,111 & 15 \\
\hline Qatar & 11,437 & 885 & 80 & Norway & 307,442 & 4,635 & 12 \\
\hline Singapore & 683 & 4,267 & 6,247 & Sweden & 410,934 & 9,066 & 20 \\
\hline Spain & 499,542 & 43,060 & 85 & United States & $9,161,923$ & 302,741 & 31 \\
\hline Taiwan & 32,260 & 22,653 & 702 & & & & \\
\hline UAE & 83,600 & 4,089 & 49 & & & & \\
\hline Average & 128,977 & 19,974 & 1,862 & Average & $1,671,229$ & 32,132 & 143 \\
\hline
\end{tabular}

Some countries are filtered out from our sample according to the following criteria:

- Even though a country is listed in year 2007, if its name is not shown at least three times or more in the past, it is ruled out. Development should be sustainable, thus Libya, Oman, and Trinidad and Tobago are ruled out.

- A country must show its name at least three times, including for 2007. It is hard to judge whether a country is really growing if its name is listed only once or twice, thus Belarus, Slovenia, Czech Republic, and Malta are ruled out.

- A country whose name is not listed in 2007 is ruled out. Developments should be currently on-going, thus Argentina, Palau, Saudi Arabia, Uruguay, and Venezuela are ruled out.

According to Table 2, countries in Group 1 (successful "take-offs") are significantly smaller with an average land area of 128,977 square kilometers than those of Group 2 ("old riches") with an average of 1,671,229. The average land area of all 190 countries is 683,879 square kilometers. In sum, the "old-rich" countries, on average, possess significantly larger territorries than the "take-off" countries as well as when compared to other average countries. It can be argued from this finding that both large and small states can experience economic development, but the "take-off" countries in Group 1 have relatively fewer populations than others. Specifically, the average population in Group 1 is almost half of Group 2 according to the entire sample and density: Countries which experienced rapid development have, on average, less population. This finding is consistent with that of Easterly and Kraay (2000), who report that "small states (in terms of population) have higher per capita GDP than other states." Finally, the difference of density in each group is striking: The density in Group 1 is 10 times higher than that of Group 2, and six times higher than that of the entire world.

On top of these variables, we consider several control variables that may affect take-off for an economy. There are many suggestions from previous papers for these variables. There is a sizable literature of documented claims regarding a positive association between economic developments and the "maturity" of capital markets and private sector corporate governance. La Porta et al. (1998) and Djankov et al. (2008) argue that the degrees of financial 
investor protection and governance enforcement are strongly and positively correlated with sustainable economic developments. The spatial determinants of economic growth may be overstated if factors which proxy for such concern are not controlled for. In this regard, we use a number of well-cited variables from the law and economics literature: For sovereign legal system indicators, we source accounting standards (AS) from La Porta, et al. (1998) and anti-director rights (AD), which proxies for the degree of shareholder protections, from Djankov et al. (2008). We also calculate the ratio of stock market capitalization to GDP (SMCTG) as a relative measure of country-specific capital market development, also suggested by Djankov et al. (2008). Table 3 summarizes these variables.

Lucas (2009) finds that "open" countries have shown better performance in terms of economic growth. We sourced the openness indicator as suggested by Sachs and Warner (1995), which defines an open (as opposed to "closed") country as a sovereign jurisdiction that satisfies the following criteria: (1) have effective protection rates less than 40 percent; (2) have quotas for less than 40 percent of imports, (3) have no currency controls or black markets in currency; (4) have no export marketing boards; and (5) are not socialist (Kornai, 1992). Eichengreen et al. (2013) showed that the ratio of "high" education positively affects economic growth. Our proxies for the degree of human capital are suggested by Barro and Lee (2012) which defines education-level indicators by measuring the proportions of graduates from the secondary and/or tertiary education programs among the population over the age of 25 .

This table presents various measures of nation-specific corporate governance. Accounting Standards (AS) is from La Porta, et al. (1998) whereas Antidirector Rights (AD), a proxy for degree of shareholder protection, and Stock Market Capitalization to GDP (SMCTG), a measure of equity market development, are suggested by Djankov, et al. (2008). Governance is considered "high" if a rating is higher than the median.

Table 3. Sovereign corporate governance measures

\begin{tabular}{|c|c|c|c|c|c|c|c|}
\hline $\begin{array}{c}\text { Group } 1 \\
\text { (19 take-offs) }\end{array}$ & AD & AS & SMCTG & $\begin{array}{c}\text { Group } 2 \\
\text { (17 old riches) }\end{array}$ & AD & $\mathbf{A S}$ & SMCTG \\
\hline Bahamas & & & & Australia & 4 & 75 & 5 \\
\hline Bermuda & & & & Austria & 3 & 54 & 2.797 \\
\hline Brunei & & & & Barbados & & & \\
\hline Chile & 4 & 52 & 4.496 & Belgium & 3 & 61 & 4.208 \\
\hline Cyprus & & & & Canada & 4 & 74 & 4.665 \\
\hline Germany & 4 & 62 & 4.002 & Denmark & 4 & 62 & 4.071 \\
\hline Greece & 2 & 55 & 4.515 & Finland & 4 & 77 & 5.177 \\
\hline Hong Kong & 5 & 69 & 5.889 & France & 4 & 69 & 4.494 \\
\hline Ireland & 5 & & 4.214 & Iceland & & & \\
\hline Japan & 5 & 65 & 4.237 & Israel & & & \\
\hline South Korea & 5 & 62 & 3.991 & Italy & 2 & 62 & 3.967 \\
\hline Kuwait & & & & Luxembourg & 2 & & 4.974 \\
\hline Macao & & & & Netherlands & 3 & 64 & 4.881 \\
\hline Puerto Rico & & & & New Zealand & 4 & 70 & 3.691 \\
\hline Qatar & & & & Norway & 4 & 74 & 3.681 \\
\hline Singapore & 5 & 78 & 5.105 & Sweden & 4 & 83 & 4.721 \\
\hline Spain & 5 & 64 & 4.381 & United States & 3 & 71 & 4.957 \\
\hline Taiwan & 3 & 65 & 4.624 & & & & \\
\hline UAE & & & & & & & \\
\hline
\end{tabular}

Against this backdrop, we consider the maturity proxies of capital markets (SMCTG: stock market capitalization to GDP) and sovereign-level governance (AD and AS), openness dummy variable (Openness), proportions on completion of secondary education and higher (Tertiary) education among the population over the age of 25 . 


\section{SIZE AND TAKE-OFF: CORRELATION ANALYSIS AND PANEL REGRESSIONS}

In Table 4, the above findings are further examined by a correlation coefficient analysis: All three size variables (Area, Population, and Density) are negatively correlated with per capita GDP in Group 1 countries with statistical significances on the area. On the other hand, we find strong positive associations between area and population, and per capital income for countries in Group 2. There appears to be stratified economic relations between the size factors and the economic status of a country, whether as a "take-off" or "old-rich." We further examined these differences by implementing panel regression analyses with control variables. ${ }^{2}$

The numerical values below are correlation coefficients with the relative per capita GDP for each country group for the following variables: Area, Population, and Density. $* * *, * *$, and * stand for statistical significance based on twosided tests at the $1 \%, 5 \%$, and $10 \%$ level, respectively. The observations are in country-years from 1955 until 2005.

Table 4. Correlations with per capita GDP

\begin{tabular}{l|c|c|c}
\hline \multicolumn{1}{c|}{ Group } & Area & Population & Density \\
\hline All & $0.063^{* *}$ & $-0.051^{* *}$ & $0.141^{* * *}$ \\
\hline Group 1 & $-0.206^{* * *}$ & -0.122 & -0.039 \\
\hline Group 2 & $0.177^{* *}$ & $0.209 * * *$ & -0.029 \\
\hline
\end{tabular}

With control variables mentioned in the previous section, this study conducts panel regressions covering 184 countries $(19,17$, and 148 countries in Groups 1, 2, and 3, respectively) and 11 five-year periods (from 1955 to 2005):

$$
\text { Growth }_{i t}=\alpha_{i}+\beta \cdot \text { Size }_{i t}+\gamma \cdot \text { Control }_{i t}+\epsilon_{i t}
$$

where the GDP growth rate (Growth) is regressed onto the key explanatory variables (Size: population, density and area), controlled for accounting standards, anti-director rights, the ratio of stock market capitalization to GDP, openness dummy variable and the respective proportions of secondary and higher education among the population of age over 25 for country $i$ and period $t$.

In Table 5, seven panel regression models of GDP growth rate are identified with aforementioned explanatory variables. In Model 1, regressed with fixed effects, the economic values of population and density are reflected in the growth rate of an average economy, although the statistical significance of density is not conspicuous. In Models 2,3 , and 4 , the spatial dimension of economic growth is augmented and regressed with generalized least squares (GLS) effects assuming heteroskedasticity, ${ }^{3}$ controlled for development proxies for capital markets (SMCTG) and capitalism (AD and AS), and further for the 1955 real GDP (Model 3) and for Groups 1 and 2 dummies (Model 4). We find that economic growth is higher the smaller the country size holding other key and control variables constant. We also observe that an economy grows faster the more mature the capitalism in terms of investor protection (AD) and accounting standards (AS). Although the negative association of economic growth and relative stock market size (SMCTG) is economically unintuitive, it can be ascribed to the real-financial lag effects.

The dependent variable is the GDP growth rate of each country. The explanatory variables are as follows: Population is in the unit of trillions. Density is the average headcound in the unit of millions per 1,000 square kilometers. Area is in the unit of billion square kilometers. For sovereign legal system indicators, we source accounting standards (AS) from La Porta et al. (1998) and anti-director rights (AD), which proxies for the degree of shareholder protection, from Djankov et al. (2008). STMCTG is the ratio of stock market capitalization to GDP as a relative measure of country-specific equity market development, suggested by Djankov et al. (2008). Openness is a dummy variable per Sachs and Warner (1995). Secondary and Tertiary variables are the respective proportions of secondary and higher education among the population of age over 25 from Barro and Lee (2012). The panel dataset is constructed per Dempster et al. (1977) and van Dyk and Meng (2001) to minimize information loss from missing

\footnotetext{
${ }^{2}$ The dataset used for panel regression analyses is constructed per Dempster et al. (1977) and van Dyk and Meng (2001) to minimize information loss from missing estimates and observations.

${ }^{3}$ These models are fitted by GLS allowing for heteroskedasticity. Additional relaxation of autocorrelation and contemporaneous correlation leaves the fitted results qualitatively equivalent.
} 
estimates and observations. The numerical value below an estimate is the $\mathrm{t}$ or $\mathrm{z}$-statistic. ***, **, and $*$ stand for statistical significance based on two-sided tests at the $1 \%, 5 \%$, and $10 \%$ level, respectively. The observations are in country-years from 1955 until 2005.

Table 5. Panel regressions of economic growth.

\begin{tabular}{|c|c|c|c|c|c|c|c|}
\hline & Model 1 & Model 2 & Model 3 & Model 4 & Model 5 & Model 6 & Model 7 \\
\hline Intercept & $\begin{array}{l}0.017 * * * \\
33.470\end{array}$ & $\begin{array}{l}-0.026^{* * * *} \\
-4.980\end{array}$ & $\begin{array}{l}-0.019 * * * \\
-3.230\end{array}$ & $\begin{array}{l}-0.012^{*} \\
-1.850\end{array}$ & $\begin{array}{l}-0.012 * * \\
-2.180\end{array}$ & $\begin{array}{l}-0.012^{* *} \\
-1.980\end{array}$ & $\begin{array}{l}-0.014 * * \\
-2.040\end{array}$ \\
\hline Population $\left(\times 10^{9}\right)$ & $\begin{array}{l}0.068^{* * * *} \\
3.890\end{array}$ & $\begin{array}{l}0.070^{* * *} \\
4.490\end{array}$ & $\begin{array}{l}0.076^{* * *} \\
4.710\end{array}$ & $\begin{array}{l}0.069 * * * \\
4.360\end{array}$ & $\begin{array}{l}0.061^{* * *} \\
3.730\end{array}$ & $\begin{array}{l}0.062^{* * * *} \\
3.720\end{array}$ & $\begin{array}{l}0.061^{* * *} \\
3.730\end{array}$ \\
\hline Density $\left(\times 10^{6} / 10^{3} \mathrm{~km}^{2}\right)$ & $\begin{array}{l}1.167 \\
1.070\end{array}$ & $\begin{array}{l}1.742 * * \\
2.340\end{array}$ & $\begin{array}{l}1.410^{* * *} \\
2.000\end{array}$ & $\begin{array}{l}1.801 * * \\
2.400\end{array}$ & $\begin{array}{l}1.659^{* *} \\
2.390\end{array}$ & $\begin{array}{l}1.603 * * \\
2.340\end{array}$ & $\begin{array}{l}1.887 * * * \\
2.580\end{array}$ \\
\hline Area $\left(\times 10^{9} \mathrm{~km} 2\right)$ & & $\begin{array}{l}-1.023 * * \\
-2.400\end{array}$ & $\begin{array}{l}-1.338^{* * * *} \\
-2.990\end{array}$ & $\begin{array}{l}-1.198 * * * \\
-2.620\end{array}$ & $\begin{array}{l}-0.879^{*} \\
-1.820\end{array}$ & $\begin{array}{l}-0.916^{*} \\
-1.860\end{array}$ & $\begin{array}{l}-1.030^{* * *} \\
-2.060\end{array}$ \\
\hline $\mathrm{AD}$ & & $\begin{array}{l}0.015 * * * \\
8.650\end{array}$ & $\begin{array}{l}0.018^{* * *} \\
8.990\end{array}$ & $\begin{array}{l}0.016^{* * * *} \\
8.640\end{array}$ & $\begin{array}{l}0.020^{* * *} \\
10.850\end{array}$ & $\begin{array}{l}0.020^{* * *} \\
10.140\end{array}$ & $\begin{array}{l}0.020^{* * *} \\
10.560\end{array}$ \\
\hline AS & & $\begin{array}{l}0.001 * * * \\
6.280\end{array}$ & $\begin{array}{l}0.001^{* * *} \\
4.110\end{array}$ & $\begin{array}{l}0.001 * * * \\
3.530\end{array}$ & $\begin{array}{l}0.001^{* * *} \\
3.860\end{array}$ & $\begin{array}{l}0.001^{* * *} \\
3.530\end{array}$ & $\begin{array}{l}0.001 * * * \\
3.270\end{array}$ \\
\hline SMCTG & & $\begin{array}{l}-0.022 * * * \\
-7.950\end{array}$ & $\begin{array}{l}-0.024 * * * \\
-8.380\end{array}$ & $\begin{array}{l}-0.022 * * * \\
-7.520\end{array}$ & $\begin{array}{l}-0.028^{* * *} \\
-9.500\end{array}$ & $\begin{array}{l}-0.028 * * * \\
-9.290\end{array}$ & $\begin{array}{l}-0.027 * * * \\
-9.020\end{array}$ \\
\hline Openness & & & & & $\begin{array}{l}0.018^{* * * *} \\
8.840\end{array}$ & $\begin{array}{l}0.018^{* * * *} \\
8.540\end{array}$ & $\begin{array}{l}0.019 * * * \\
8.530\end{array}$ \\
\hline Secondary & & & & & $\begin{array}{l}0.001 * * * \\
9.320\end{array}$ & $\begin{array}{l}0.001 * * * \\
9.120\end{array}$ & $\begin{array}{l}0.001^{* * * *} \\
9.160\end{array}$ \\
\hline Tertiary & & & & & $\begin{array}{l}-0.001 * * * \\
-3.650\end{array}$ & $\begin{array}{l}-0.001 * * * \\
-3.570\end{array}$ & $\begin{array}{l}-0.001 * * * \\
-3.610\end{array}$ \\
\hline Fixed effects & Yes & No & No & No & No & No & No \\
\hline GLS effects & No & Yes & Yes & Yes & Yes & Yes & Yes \\
\hline 1955 real GDP dummy & No & No & Yes & No & No & Yes & No \\
\hline Group 1 dummy & No & No & No & Yes & No & No & Yes \\
\hline Group 2 dummy & No & No & No & Yes & No & No & Yes \\
\hline Number of observations & 1,958 & 1,958 & 1,958 & 1,958 & 1,958 & 1,958 & 1,958 \\
\hline $\mathrm{R}^{2}$ & 0.005 & 0.087 & 0.092 & 0.092 & 0.120 & 0.121 & 0.121 \\
\hline
\end{tabular}

The spatial effect findings of economic growth are robust to the country-level degrees of economic openness and education level as exhibited in Models 5, 6, 7, which are fitted with GLS effects and additionally controlled for the 1955 real GDP (Model 6) and for Groups 1 and 2 dummies (Model 7). A country experiences a more accelerated economic growth the more it is internationally open, and/or the higher its relative population in secondary education. Over-education may explain the negative association between economic growth and tertiary education.

In sum, on average, an economy appears to grow faster the smaller the landmass, and/or the larger the potential workforce, and/or the higher the population density, controlled for the quality indices of capital markets, economic regime, openness, and human capital. We now turn to discussing the transition from take-off to slow-down by considering the non-linear aspects of economic growth in the next section.

\section{SUSTAINABILITY OF TAKE-OFF AND SLOW-DOWN OF AN ECONOMY}

Take-off is not sustainable by nature and an economy may slow down after a certain period of rapid growth regardless of its size. While we looked at the overall relationship between economic growth and its determinants in Section 3, this section focuses on Group 1 countries, or the so-called "take-offs," specifically their economic propulsions and sequential contractions. A typical Group 1 country will not grow fast for good: Like an athlete who leaps in a long jump game will land after a short flight, an economy will decelerate after a certain period of high 
degree of growth. According to Kuznets's "inverted U hypothesis," a country's growth rate tends to rise as its income increases, but decreases as its income exceeds a certain threshold.

For the sample countries in Group 1, this paper tests this hypothesis. In order to facilitate the concave nature of the hypothesis, we propose a non-linear model as follows:

$$
G=y^{\alpha} e^{-\beta y}
$$

where $G$ is the growth rate of each country, and $y$ is the per capita GDP relative ${ }^{4}$ to that of the U.S. which was used in previous section as an explanatory variable. Non-linear model in equation (2) has an important mathematical advantage in that it can detect the point of reflection when an economy starts its slow-down, which cannot be captured by a typical quadratic equation. Visual shapes of each model are provided in Figure 1.

Table 6 provides the regression results of selected Group 1 countries. $^{5}$ Out of 19 countries, seven has positive coefficient estimates for both $\alpha$ and $\beta$. Singapore is chosen since it is one of the typical take-off examples. Moreover, its coefficient of $\alpha$ is significant, and that of $\beta$ is nearly significant with a $p$-value equal to 0.118 .

Equation (2) appears to well capture the growth patterns of selected countries. These countries appear to show a wide range of variations in relative income: (Japan: $20 \rightarrow 90 \%$; Korea: $11 \rightarrow 55 \%$; Taiwan: $8 \rightarrow 61 \%$ ). These noticeable performances indicate their successful take-offs, and with these wide ranges, Equation (2) is deemed to provide a desirable fit to these countries. Detailed discussions on some of the prominent take-off countries are followed.

Figure 1. Comparison of our non-linear model and standard quadratic non-linear model

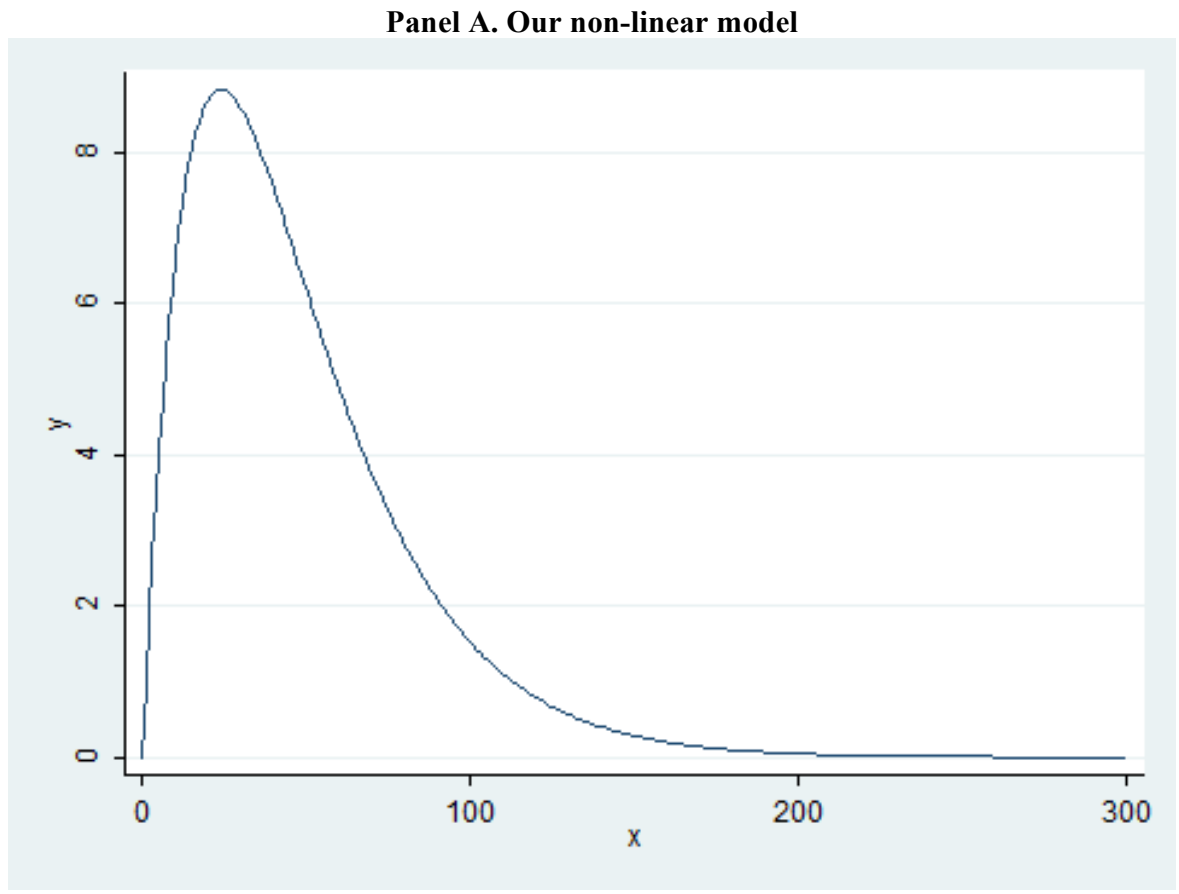

\footnotetext{
${ }^{4}$ The U.S. is a numéraire country used to compare various per capita GDPs of sample countries.

${ }^{5}$ The results for the entire countries are available upon request.
} 
Panel B. Standard quadratic model

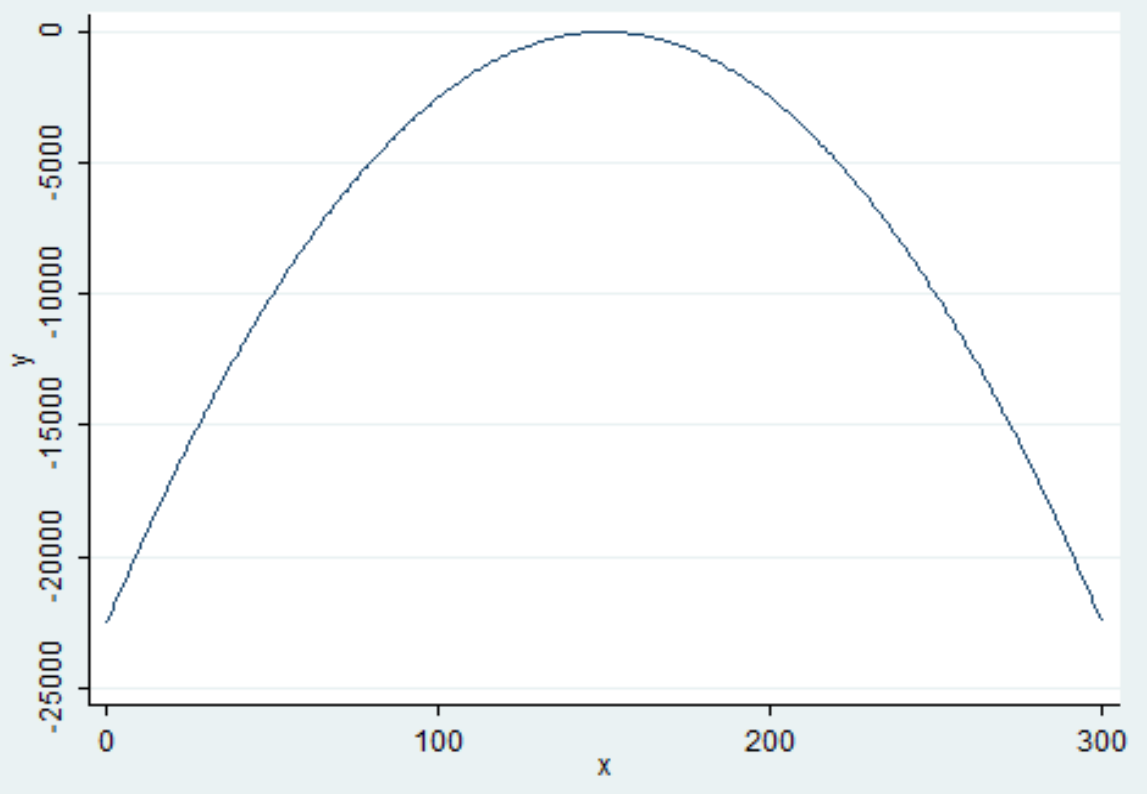

The non-linear model is as follows:

$$
G=I^{\alpha} e^{-\beta I}
$$

where $\mathrm{G}$ is the growth rate of each country, and $\mathrm{I}$ is the per capita GDP relative to that of the U.S. The numerical values below coefficient estimates are the t-statistics. $* * *, * *$, and $*$ stand for statistical significance based on two-sided tests at the $1 \%, 5 \%$, and $10 \%$ level, respectively.

Table 6. Non-linear regressions for Group 1 countries

\begin{tabular}{|c|c|c|c|c|c|}
\hline Country & & $\beta$ & Country & & $\beta$ \\
\hline Bahamas & $\begin{array}{r}-2.756 \\
1.969\end{array}$ & $\begin{array}{r}-0.175 \\
0.000\end{array}$ & South Korea & $\begin{array}{l}0.785 * * * \\
0.115\end{array}$ & $\begin{array}{l}0.028 * * \\
0.000\end{array}$ \\
\hline Bermuda & $\begin{array}{r}-0.646 \\
1.235\end{array}$ & $\begin{array}{r}-0.032 \\
0.000\end{array}$ & Kuwait & $\begin{array}{l}0.536 \\
4.400\end{array}$ & $\begin{array}{l}0.032 \\
0.000\end{array}$ \\
\hline Brunei & $\begin{array}{r}-2.165 \\
2.336\end{array}$ & $\begin{array}{r}-0.051 \\
0.000\end{array}$ & Macao & $\begin{array}{r}-0.214 \\
0.202\end{array}$ & $\begin{array}{l}-0.036 \text { *** } \\
0.000\end{array}$ \\
\hline Chile & $\begin{array}{r}-0.271 \\
0.730\end{array}$ & $\begin{array}{r}-0.055 \\
0.000\end{array}$ & Puerto Rico & $\begin{array}{l}0.907 * * * \\
0.220\end{array}$ & $\begin{array}{l}0.048 \text { *** } \\
0.000\end{array}$ \\
\hline Cyprus & $\begin{array}{l}0.623 * \\
0.320\end{array}$ & $\begin{array}{l}0.019 \\
0.000\end{array}$ & Qatar & $\begin{array}{l}1.571 \\
3.474\end{array}$ & $\begin{array}{l}0.075 \\
0.000\end{array}$ \\
\hline Germany & $\begin{array}{l}0.085 \\
1.145\end{array}$ & $\begin{array}{r}-0.004 \\
0.000\end{array}$ & Singapore & $\begin{array}{l}0.604 \text { *** } \\
0.123\end{array}$ & $\begin{array}{l}0.013 \\
0.000\end{array}$ \\
\hline Greece & $\begin{array}{l}0.808 * * * \\
0.244\end{array}$ & $\begin{array}{l}0.037 * \\
0.000\end{array}$ & Spain & $\begin{array}{l}0.944 * * * \\
0.181\end{array}$ & $\begin{array}{l}0.044 * * * \\
0.000\end{array}$ \\
\hline Hong Kong & $\begin{array}{l}0.836 \text { *** } \\
0.100\end{array}$ & $\begin{array}{l}0.027 \text { *** } \\
0.000\end{array}$ & Taiwan & $\begin{array}{l}0.926 \text { *** } \\
0.056\end{array}$ & $\begin{array}{l}0.039 * * * \\
0.000\end{array}$ \\
\hline Ireland & $\begin{array}{l}0.165 \\
0.148\end{array}$ & $\begin{array}{r}-0.011 \\
0.000\end{array}$ & UAE & $\begin{array}{l}0.232 \\
0.800\end{array}$ & $\begin{array}{r}-0.013 \\
0.000\end{array}$ \\
\hline Japan & $\begin{array}{l}1.002 \text { *** } \\
0.076\end{array}$ & $\begin{array}{l}0.042 \text { *** } \\
0.000\end{array}$ & & & \\
\hline
\end{tabular}

Japan, South Korea, and Taiwan are selected based on their relatively high model fit and similarity in terms of development processes. We begin with Japan. 


\subsection{Japan}

Japan is the first country in East Asia that experienced the "take-off." Ever since its opening in the Meiji Revolution, Japan's policies differentiated from its neighboring countries by actively accepting systems and cultures of the West (脱亜入欧, だつあにゆうおう: Leave Asia and Enter Europe). Even though its economy was destroyed at the end of World War II, it was revived by taking advantage of the Korean War. Its relative income in 1950 was already $20 \%$ of the U.S., which was the highest among all neighboring countries as China was $2.6 \%$ in 1952, Korea was $10.6 \%$ in 1953, the Philippines was $12.9 \%$ in 1950 , and Taiwan was $7.7 \%$ in 1951.

A full-fledged take off began around 1958 when its income was $32.3 \%$ of the U.S. It took eight years (1950 $\rightarrow$ 1958 ) for its income to increase from $20 \%$ to $30 \%$, but only three years $(1958 \rightarrow 1961)$ from $30 \%$ to $40 \%$. Remarkably, after the golden era of the 1960 s and having hosted the Olympics, its income leaped to $70 \%$ of the U.S. in 1970 .

However, as shown in Panel A of Figure 2, the steep increase stagnated since 1970, mainly due to the first Oil Shock. It took 12 years to reach the $80 \%$ level $(1970 \rightarrow 1982)$. In the 1980s (until 1988), the relative income level had almost stagnated (81\% in 1982 and 82\% in 1988). An interesting phenomenon was observed between 1988 and 1991 when the income level surged from $82 \%$ to $90.3 \%$, thus reminding us of Japan's golden era in the 1960s. However, this is mainly due to the yen appreciation, not to the economic growth. Since the Plaza Accord in 1985, yen against dollar had appreciated more than $50 \%$, so the nominal value of Japan's income level, expressed in terms of dollars, has increased without "real" growth. In other words, it was a temporary bubble. The evidence of this argument is the trend since 1991: The income level soon went back to $80 \%$ in 1997. However, coupled with a deep recession, Japan's relative income is now only $70 \%$ of the U.S., which is the same level as in 1970.

Figure 2. Panel A. Japan

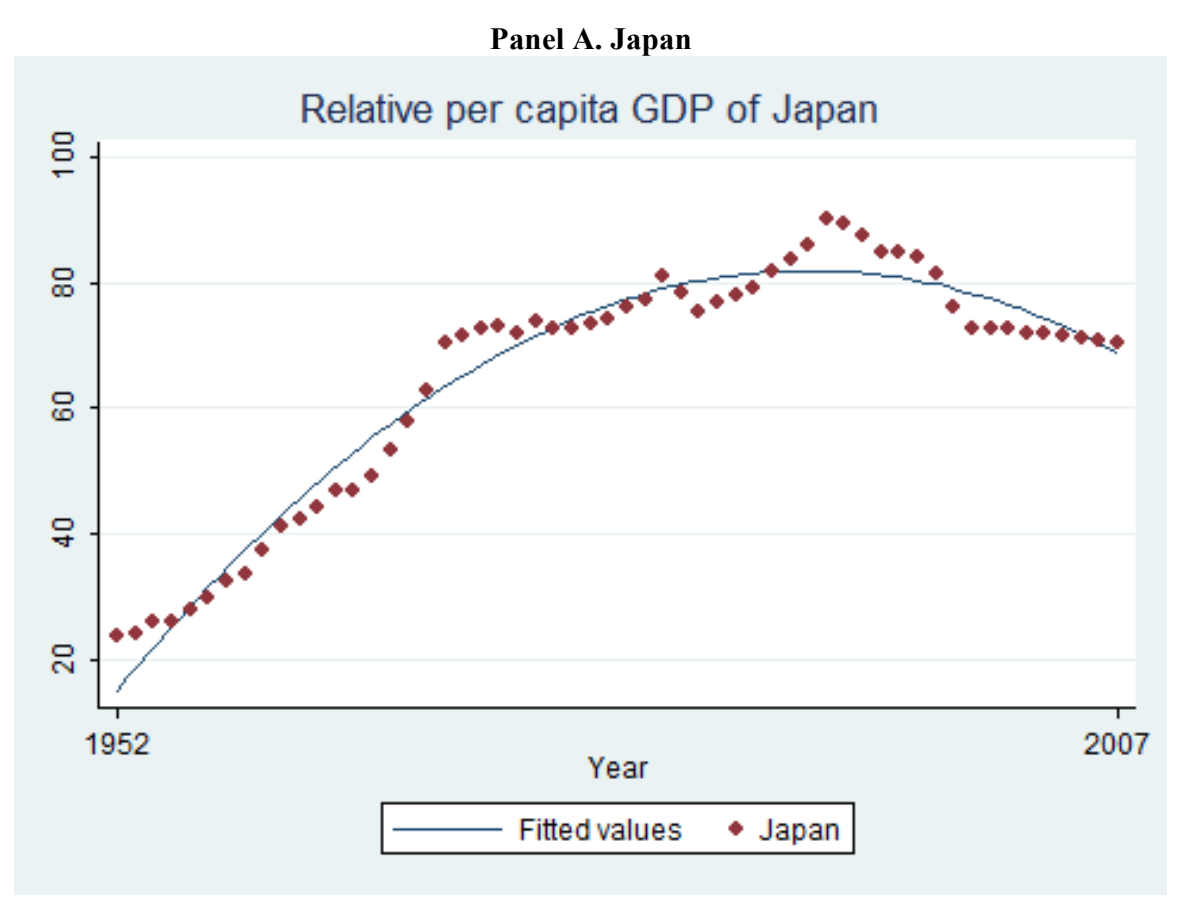


Panel B. South Korea

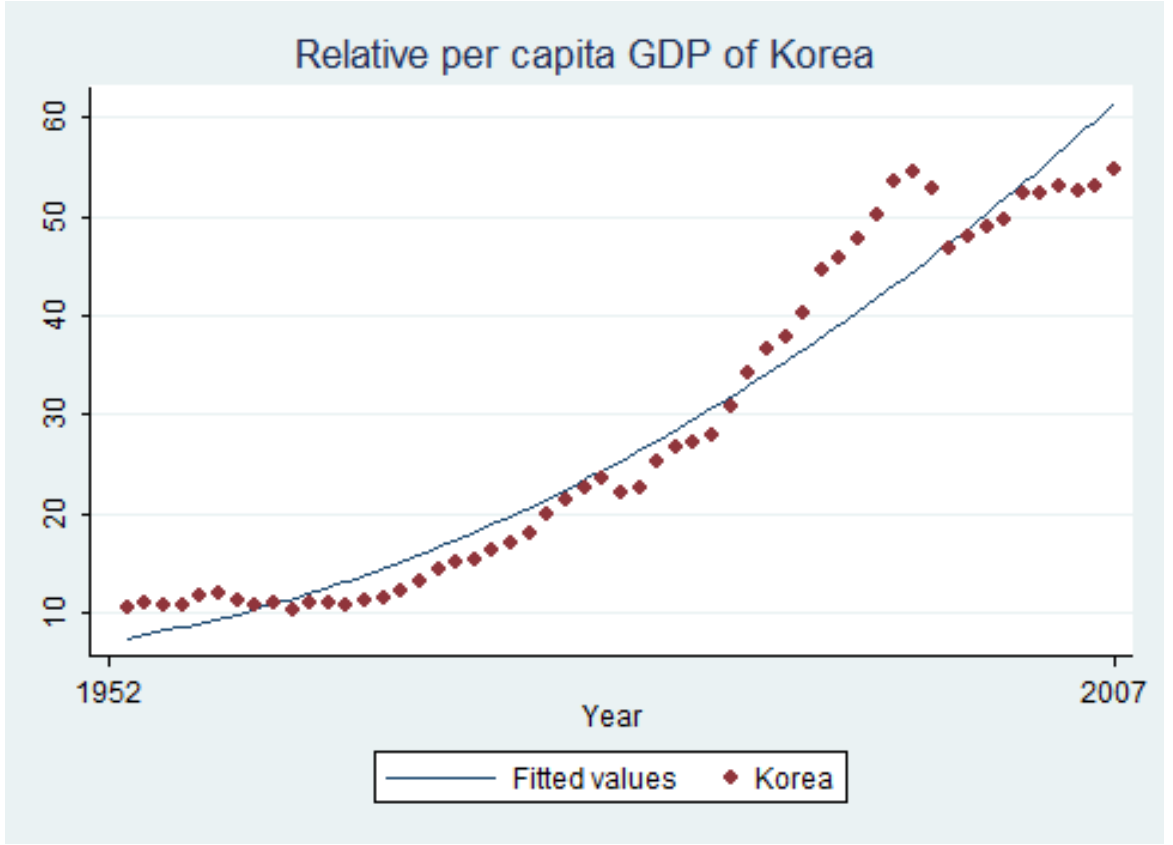

Panel C. Taiwan

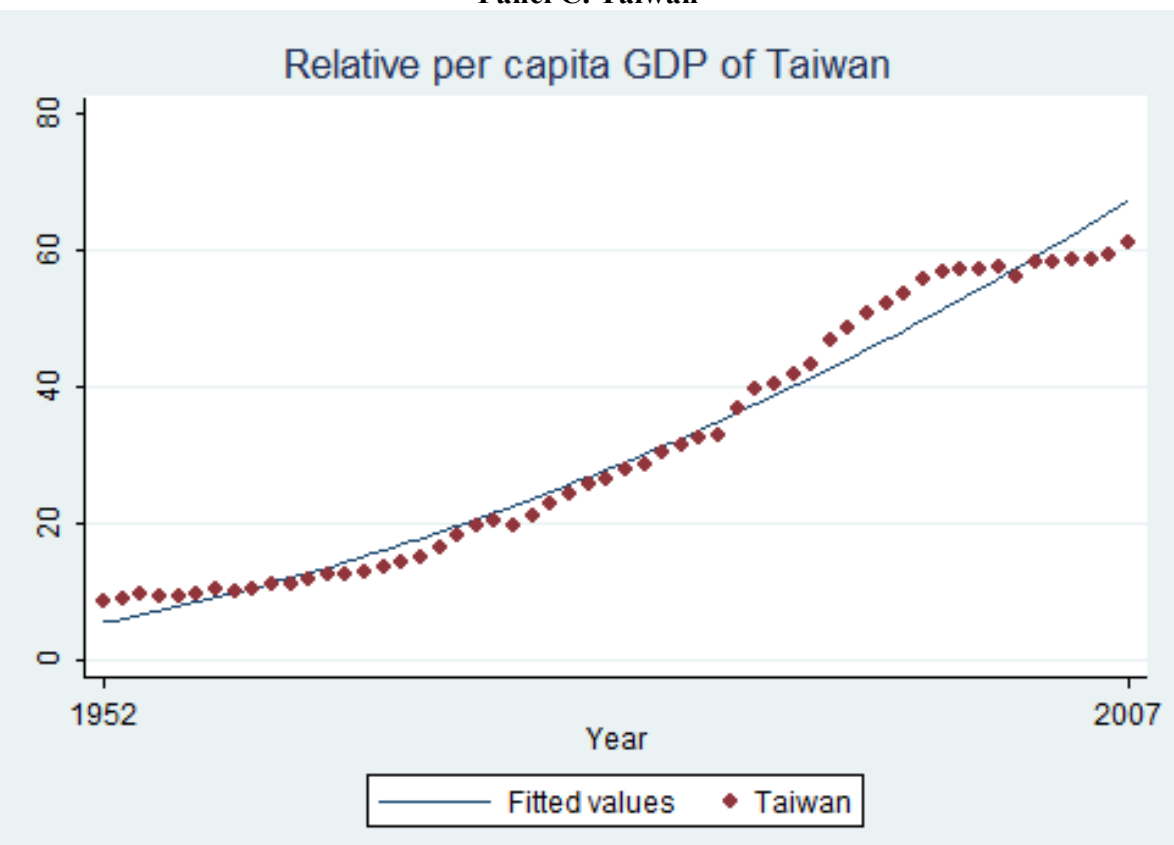

\subsection{South Korea}

Korea showed no progress in the 1950s and early 1960s. Its relative income in 1953 was $10.6 \%$ of the U.S. and the income in 1962 was $10.4 \%$ of the U.S. However, since General Park Chung Hee overtook presidency through a military coup in 1961, its economy took off and its income had exceeded 20\% of the U.S. in 1977 (Panel B, Figure 2). Its upward trend had continued in the 1980s and 1990s as its income exceeded $30 \%, 40 \%$, and $50 \%$ in 1986 , 
1990, and 1994, respectively. Due to the unprecedented currency depreciation after the financial crisis and IMF bailout in the late 1990's, its relative income dropped from 52.8\% in 1997 to $46.6 \%$ in 1998. However, it recovered from the aftermath of the crisis, and exceeded the $50 \%$ level in 2002. Unlike Japan, the relative income of Korea is still in an increasing phase; Japan is at around $70 \%$ with a decreasing trend, while Korea is around 55\% and still increasing. It may be premature to predict, but it is likely that these two economies' relative income level may converge in a decade or so. The PPP based per capita income of the two countries had already converged at around $\$ 28,000$.

To South Korea, potential reunification with North Korea may also poses a big external shock to its economy. With a successful transition to a merged entity, the unified Korea's economy may undergo a second round of rapid growth and become a leading economy in Asia.

\subsection{Taiwan}

Taiwan's development pattern is similar to that of Korea's, but with a more stable trend. After being stagnated at around $10 \%$ of U.S. income, its take-off began in mid 1960s due to implementations of its reform and open economy policy. Its income achieved $20 \%, 30 \%, 40 \%$, and $50 \%$ relative to that of the U.S. in $1973,1982,1988$, and 1993, respectively (Panel C, Figure 2). Up to this point, Taiwan's development pattern is very similar to that of Korea's. However, unlike Korea that was devastated in the financial crisis in 1997, Taiwan was not much affected and its relative income levels did not experience sudden shrinkages. Due to the stable growth, its income level has achieved $60 \%$ of the U.S.

\subsection{Predictions of Future Take-Offs: Special Reference to China}

Descriptions on countries that have already experienced "take-offs" may be useful for predicting the growth patterns of developing countries that are about to take off and join Group 1. Given that most countries in Group 1 are small in terms of area and population, those small developing countries with the potentials to take-off will be good candidates. However, it appears that current rapidly growing countries are mostly large in terms of area and population: Consider China, for example. According to Table 7 China has shown a double-digit growth rate since 2004, and its relative income has doubled in less than 10 years. China is deemed a likely candidate for the next Group 1 member country. Performances of other large countries, such as Brazil, Russia, and India as so-called "BRICS," are not as conspicuous as China: The income of Brazil has increased to 22\% of the U.S. in 2007 from $16 \%$ in 1950; India from $6 \%$ to $9 \%$ in the last half century. Russian income records an overall decrease. Emerging markets in Southeast Asia, such as Malaysia, Indonesia, Thailand, and Vietnam have also shown increasing trends of relative income, but the process is not as impressive as the countries in Group 1 and China. Moreover, among the current developing economies, China shows a very significant non-linear regression result according to our untabulated report. $^{6}$

For this reason, this section focuses on China. More specifically, by looking at the data of several Group 1 countries, we attempted to predict how long the Chinese economy will remain "airborne" until when it will eventually slow down. First, consider the fitted result of China and the shape of Equation (2) in Figure 3. Mathematically, this function has a relatively long tail, meaning that its decreasing part is initially concave but becomes convex at a certain point. The decreasing rate is diminishing at a certain point, and the reflection point may be a starting point for the economy's slowdown.

\footnotetext{
${ }^{6}$ The non-linear regression results are available upon request.
} 
Per capita income of eight countries in Group 1 and prospective countries (BRICS, Malaysia, Indonesia, Thailand, and Vietnam) for the group relative to the U.S in percent.

Table 7. Per capita income of eight countries in Group 1 and selected countries

Panel A: Japan-Greece

\begin{tabular}{|c|c|c|c|c|c|c|c|}
\hline Year & Japan & Korea & Tai-wan & Hong Kong & Singapore & Spain & Greece \\
\hline 1952 & 23.473 & & 8.422 & & & 30.840 & 28.017 \\
\hline 1953 & 23.861 & 10.612 & 8.821 & & & 29.059 & 30.445 \\
\hline 1954 & 25.818 & 11.018 & 9.348 & & & 33.798 & 31.352 \\
\hline 1955 & 26.099 & 10.892 & 9.115 & & & 32.967 & 31.232 \\
\hline 1956 & 27.661 & 10.709 & 8.970 & & & 35.122 & 33.807 \\
\hline 1957 & 29.592 & 11.654 & 9.446 & & & 36.738 & 36.222 \\
\hline 1958 & 32.263 & 12.046 & 10.054 & & & 39.472 & 39.176 \\
\hline 1959 & 33.504 & 11.301 & 9.934 & & & 35.693 & 38.418 \\
\hline 1960 & 37.180 & 10.899 & 10.337 & 23.419 & 26.833 & 38.898 & 38.200 \\
\hline 1961 & 41.023 & 11.069 & 10.791 & 23.907 & 27.084 & 43.243 & 42.311 \\
\hline 1962 & 42.471 & 10.392 & 10.961 & 24.793 & 27.280 & 45.197 & 40.685 \\
\hline 1963 & 44.152 & 11.041 & 11.669 & 28.609 & 26.724 & 47.600 & 43.328 \\
\hline 1964 & 47.035 & 11.102 & 12.427 & 30.174 & 24.838 & 47.532 & 44.767 \\
\hline 1965 & 46.809 & 10.771 & 12.386 & 33.483 & 24.083 & 47.324 & 45.984 \\
\hline 1966 & 49.077 & 11.304 & 12.730 & 33.875 & 24.607 & 48.498 & 46.457 \\
\hline 1967 & 53.469 & 11.617 & 13.600 & 34.186 & 25.720 & 49.957 & 48.022 \\
\hline 1968 & 57.701 & 12.142 & 14.001 & 33.465 & 27.419 & 50.609 & 48.825 \\
\hline 1969 & 62.855 & 13.310 & 14.786 & 36.047 & 28.202 & 53.880 & 52.522 \\
\hline 1970 & 70.330 & 14.426 & 16.463 & 38.832 & 30.914 & 56.033 & 57.481 \\
\hline 1971 & 71.495 & 15.044 & 18.009 & 41.081 & 33.560 & 56.562 & 60.308 \\
\hline 1972 & 72.741 & 15.272 & 19.553 & 43.189 & 35.877 & 58.309 & 62.838 \\
\hline 1973 & 73.130 & 16.256 & 20.416 & 44.457 & 38.624 & 59.381 & 64.334 \\
\hline 1974 & 71.957 & 17.132 & 19.611 & 43.451 & 41.876 & 62.539 & 61.061 \\
\hline 1975 & 73.842 & 18.016 & 20.894 & 44.957 & 43.183 & 63.287 & 64.505 \\
\hline 1976 & 72.557 & 19.844 & 22.914 & 49.621 & 43.849 & 61.451 & 64.894 \\
\hline 1977 & 72.757 & 21.391 & 24.060 & 52.774 & 44.762 & 60.080 & 63.573 \\
\hline 1978 & 73.538 & 22.593 & 25.544 & 53.767 & 46.282 & 58.049 & 64.535 \\
\hline 1979 & 74.170 & 23.522 & 26.282 & 56.155 & 49.251 & 56.673 & 64.216 \\
\hline 1980 & 76.193 & 22.104 & 27.656 & 63.135 & 54.780 & 57.858 & 65.321 \\
\hline 1981 & 77.305 & 22.719 & 28.559 & 65.319 & 56.268 & 55.116 & 63.274 \\
\hline 1982 & 80.980 & 25.328 & 30.399 & 69.662 & 61.902 & 57.114 & 63.018 \\
\hline 1983 & 78.365 & 26.757 & 31.536 & 68.903 & 65.095 & 55.054 & 59.330 \\
\hline 1984 & 75.254 & 27.273 & 32.475 & 71.382 & 63.327 & 52.335 & 55.705 \\
\hline 1985 & 76.972 & 27.909 & 32.956 & 71.235 & 57.938 & 52.048 & 55.094 \\
\hline 1986 & 78.049 & 30.837 & 36.612 & 74.281 & 56.222 & 53.661 & 54.686 \\
\hline 1987 & 79.055 & 34.101 & 39.565 & 81.640 & 58.438 & 55.603 & 52.079 \\
\hline 1988 & 81.991 & 36.628 & 40.203 & 84.544 & 61.632 & 57.038 & 53.088 \\
\hline 1989 & 83.868 & 37.727 & 41.603 & 85.220 & 65.134 & 58.413 & 53.021 \\
\hline 1990 & 86.010 & 40.311 & 43.049 & 87.357 & 68.443 & 60.166 & 52.423 \\
\hline 1991 & 90.326 & 44.617 & 46.598 & 93.852 & 73.319 & 62.823 & 54.804 \\
\hline 1992 & 89.488 & 45.893 & 48.646 & 97.403 & 75.093 & 62.146 & 53.410 \\
\hline 1993 & 87.516 & 47.744 & 50.770 & 100.661 & 80.977 & 59.472 & 51.587 \\
\hline 1994 & 84.809 & 50.213 & 52.068 & 99.068 & 84.723 & 58.706 & 51.048 \\
\hline 1995 & 84.919 & 53.500 & 53.635 & 94.585 & 89.270 & 59.754 & 51.415 \\
\hline 1996 & 84.027 & 54.370 & 55.590 & 94.303 & 91.215 & 59.354 & 51.194 \\
\hline 1997 & 81.282 & 52.780 & 56.756 & 94.348 & 92.648 & 59.119 & 51.041 \\
\hline 1998 & 76.073 & 46.636 & 57.035 & 86.302 & 81.820 & 59.918 & 50.872 \\
\hline 1999 & 72.698 & 48.074 & 57.191 & 83.609 & 80.574 & 60.775 & 50.841 \\
\hline 2000 & 72.601 & 48.805 & 57.403 & 86.316 & 89.541 & 61.678 & 51.253 \\
\hline 2001 & 72.761 & 49.697 & 56.210 & 86.689 & 81.894 & 64.606 & 53.406 \\
\hline 2002 & 72.118 & 52.220 & 58.205 & 88.419 & 82.222 & 66.586 & 55.666 \\
\hline 2003 & 71.832 & 52.363 & 58.291 & 87.272 & 79.949 & 68.060 & 58.395 \\
\hline 2004 & 71.535 & 53.089 & 58.569 & 88.254 & 88.786 & 68.308 & 59.793 \\
\hline 2005 & 71.125 & 52.659 & 58.703 & 91.129 & 91.810 & 69.621 & 60.824 \\
\hline
\end{tabular}


(Table 7 continued)

\section{Panel B: China-Vietnam}

\begin{tabular}{|c|c|c|c|c|c|c|c|c|}
\hline Year & China & Brazil & India & Russia & Malaysia & Indonesia & Thai-land & Vietnam \\
\hline 1952 & 2.644 & 17.040 & 6.103 & & & & 8.400 & \\
\hline 1953 & 2.718 & 16.688 & 6.163 & & & & 7.480 & \\
\hline 1954 & 2.807 & 18.319 & 6.461 & & & & 8.004 & \\
\hline 1955 & 2.725 & 17.583 & 6.026 & & 14.773 & & 7.000 & \\
\hline 1956 & 2.922 & 17.563 & 6.102 & & 14.337 & & 7.016 & \\
\hline 1957 & 3.014 & 18.838 & 6.032 & & 13.635 & & 7.730 & \\
\hline 1958 & 3.394 & 20.111 & 6.549 & & 13.173 & & 7.936 & \\
\hline 1959 & 3.241 & 20.083 & 6.282 & & 14.775 & & 8.205 & \\
\hline 1960 & 3.155 & 20.940 & 6.525 & & 15.679 & 5.238 & 8.820 & \\
\hline 1961 & 2.714 & 23.137 & 6.638 & & 15.165 & 5.230 & 8.951 & \\
\hline 1962 & 2.596 & 22.488 & 6.493 & & 14.671 & 5.234 & 9.004 & \\
\hline 1963 & 2.609 & 22.635 & 6.627 & & 14.356 & 4.772 & 9.206 & \\
\hline 1964 & 2.705 & 21.920 & 6.633 & & 14.146 & 4.562 & 9.157 & \\
\hline 1965 & 2.782 & 21.677 & 6.065 & & 14.253 & 4.161 & 9.108 & \\
\hline 1967 & 2.661 & 21.434 & 5.902 & & 13.484 & 3.849 & 10.052 & \\
\hline 1968 & 2.410 & 22.216 & 5.829 & & 12.960 & 4.207 & 10.281 & \\
\hline 1969 & 2.518 & 21.953 & 6.161 & & 13.600 & 4.222 & 10.530 & \\
\hline 1970 & 2.726 & 24.455 & 6.232 & & 14.020 & 4.603 & 11.210 & 4.549 \\
\hline 1971 & 2.787 & 26.065 & 6.237 & & 15.885 & 4.745 & 10.846 & 4.492 \\
\hline 1972 & 2.673 & 27.167 & 5.853 & & 15.526 & 4.934 & 10.436 & 4.276 \\
\hline 1973 & 2.709 & 28.746 & 5.591 & & 17.349 & 5.363 & 11.206 & 3.923 \\
\hline 1974 & 2.799 & 31.038 & 5.540 & & 19.008 & 6.388 & 11.324 & 4.015 \\
\hline 1975 & 2.966 & 31.773 & 5.869 & & 17.936 & 6.543 & 11.598 & 4.073 \\
\hline 1976 & 2.833 & 33.219 & 5.793 & & 20.007 & 6.560 & 11.796 & 4.214 \\
\hline 1977 & 2.847 & 32.785 & 5.809 & & 20.700 & 6.983 & 12.295 & 4.506 \\
\hline 1978 & 3.013 & 31.841 & 5.826 & & 20.560 & 7.083 & 12.982 & 4.265 \\
\hline 1979 & 3.241 & 32.683 & 5.499 & & 22.436 & 8.024 & 12.739 & 4.393 \\
\hline 1980 & 3.573 & 35.165 & 5.797 & & 24.576 & 9.384 & 13.393 & 4.280 \\
\hline 1981 & 3.725 & 31.834 & 5.956 & & 23.791 & 9.767 & 13.678 & 4.341 \\
\hline 1984 & 4.599 & 28.927 & 5.959 & & 25.665 & 9.870 & 14.162 & 4.706 \\
\hline 1985 & 4.978 & 28.317 & 6.044 & & 23.590 & 9.722 & 13.797 & 4.701 \\
\hline 1986 & 5.185 & 30.122 & 6.161 & & 20.657 & 9.352 & 13.986 & 4.647 \\
\hline 1987 & 5.523 & 29.560 & 6.252 & & 21.704 & 9.406 & 14.694 & 4.595 \\
\hline 1988 & 5.685 & 28.117 & 6.387 & & 22.767 & 9.279 & 15.754 & 4.543 \\
\hline 1989 & 5.610 & 26.574 & 6.397 & & 23.504 & 9.749 & 16.786 & 4.491 \\
\hline 1990 & 5.917 & 25.585 & 6.557 & 41.356 & 24.801 & 10.603 & 18.456 & 4.802 \\
\hline 1991 & 6.507 & 25.687 & 6.571 & 42.138 & 26.808 & 11.420 & 20.309 & 5.101 \\
\hline 1992 & 7.099 & 24.720 & 6.553 & 37.388 & 28.162 & 11.798 & 21.704 & 5.263 \\
\hline 1993 & 8.052 & 24.772 & 6.583 & 29.367 & 29.741 & 12.074 & 22.742 & 5.277 \\
\hline 1994 & 8.673 & 24.893 & 6.619 & 23.807 & 30.992 & 12.249 & 23.438 & 5.308 \\
\hline 1995 & 9.274 & 25.198 & 6.922 & 21.936 & 33.277 & 12.821 & 24.669 & 5.618 \\
\hline 1996 & 9.758 & 24.635 & 6.844 & 20.395 & 34.992 & 13.226 & 25.123 & 5.792 \\
\hline 1997 & 9.838 & 24.084 & 6.864 & 19.337 & 35.001 & 13.348 & 23.046 & 5.979 \\
\hline 1998 & 9.976 & 22.843 & 6.967 & 17.365 & 32.079 & 12.074 & 19.360 & 6.050 \\
\hline 1999 & 10.257 & 21.623 & 7.260 & 18.634 & 32.486 & 11.048 & 18.793 & 6.111 \\
\hline 2000 & 10.570 & 21.544 & 7.098 & 21.607 & 33.655 & 11.214 & 18.557 & 6.171 \\
\hline 2001 & 11.408 & 21.530 & 7.296 & 21.540 & 32.847 & 11.336 & 18.700 & 6.485 \\
\hline 2002 & 12.377 & 21.850 & 7.316 & 22.094 & 34.009 & 11.299 & 19.436 & 6.713 \\
\hline 2003 & 13.280 & 21.385 & 7.531 & 23.604 & 35.811 & 11.673 & 20.521 & 6.894 \\
\hline 2004 & 14.081 & 21.662 & 7.686 & 25.529 & 37.466 & 11.465 & 20.978 & 7.200 \\
\hline 2005 & 15.483 & 21.496 & 8.038 & 27.703 & 39.363 & 11.664 & 20.698 & 7.777 \\
\hline
\end{tabular}


Figure 3. Scatter plots and non-linear fitted growth curves of Japan, South Korea, Taiwan, and China
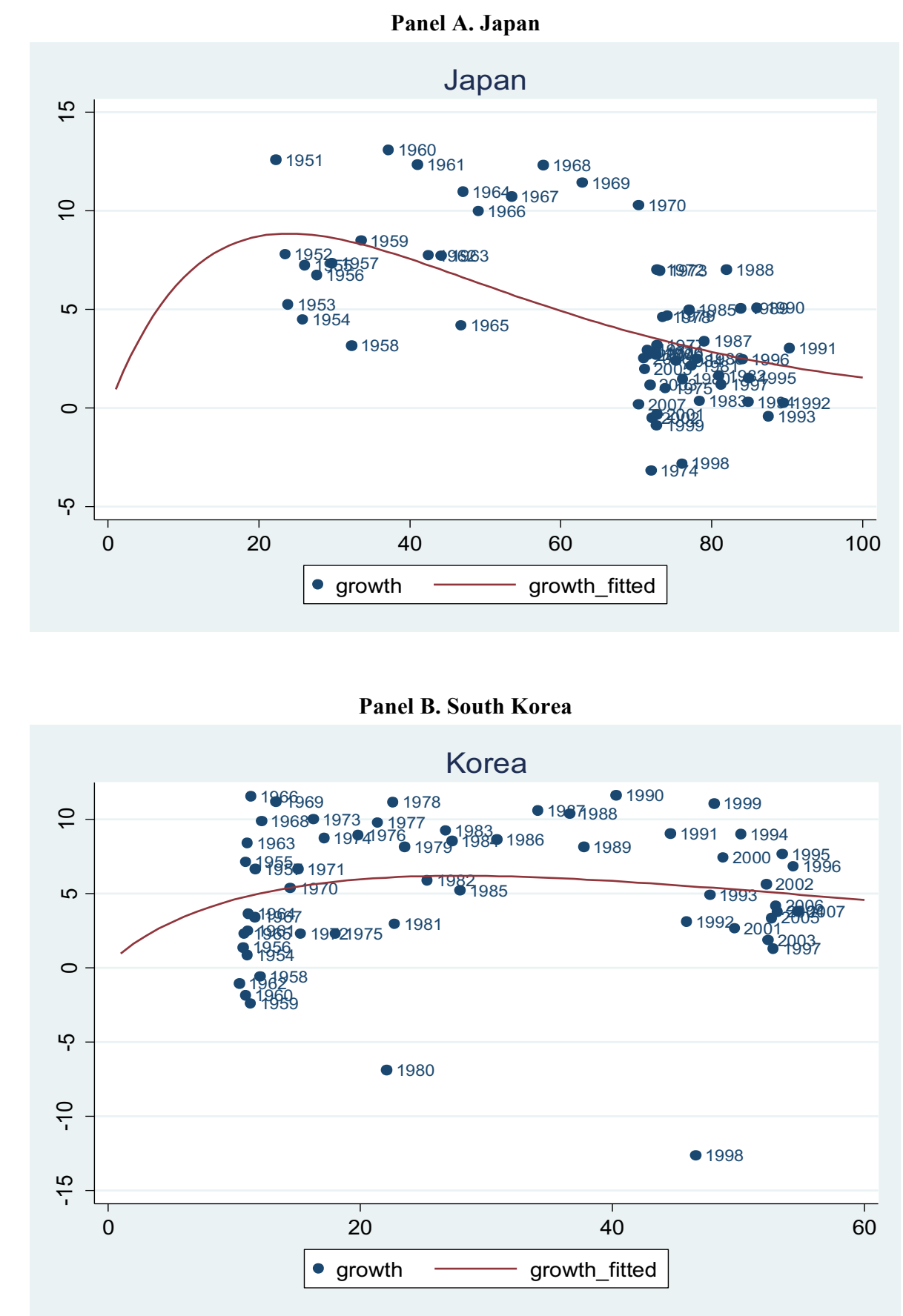
Panel C. Taiwan

\section{Taiwan}

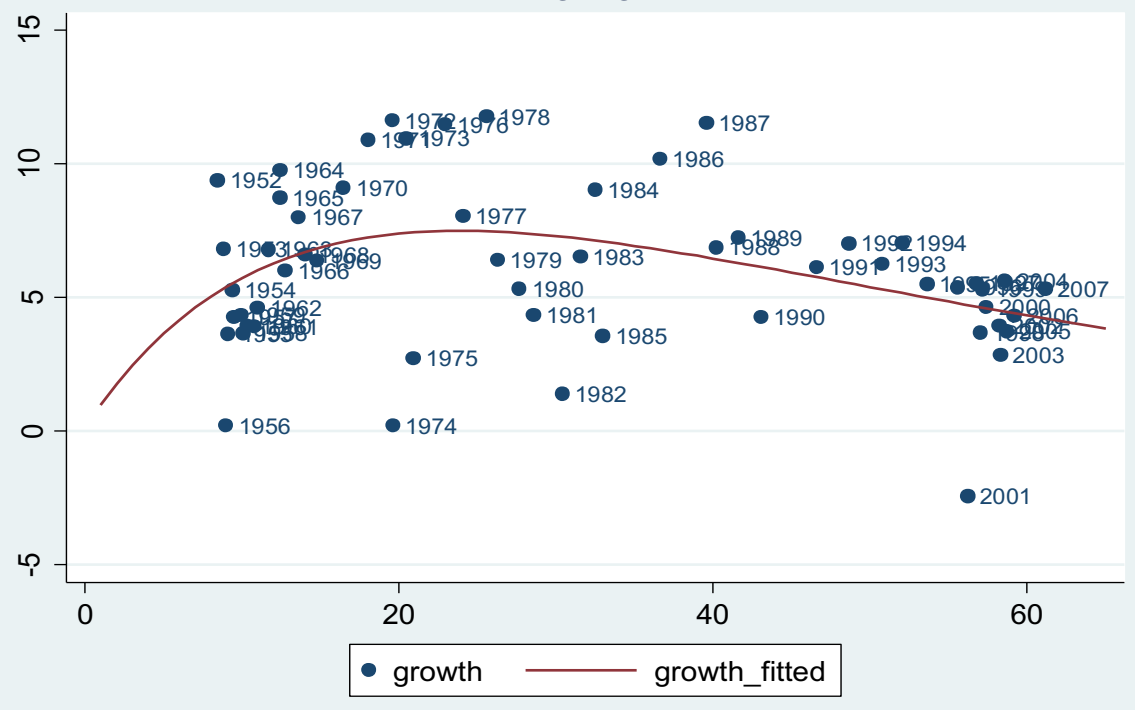

Panel D. China

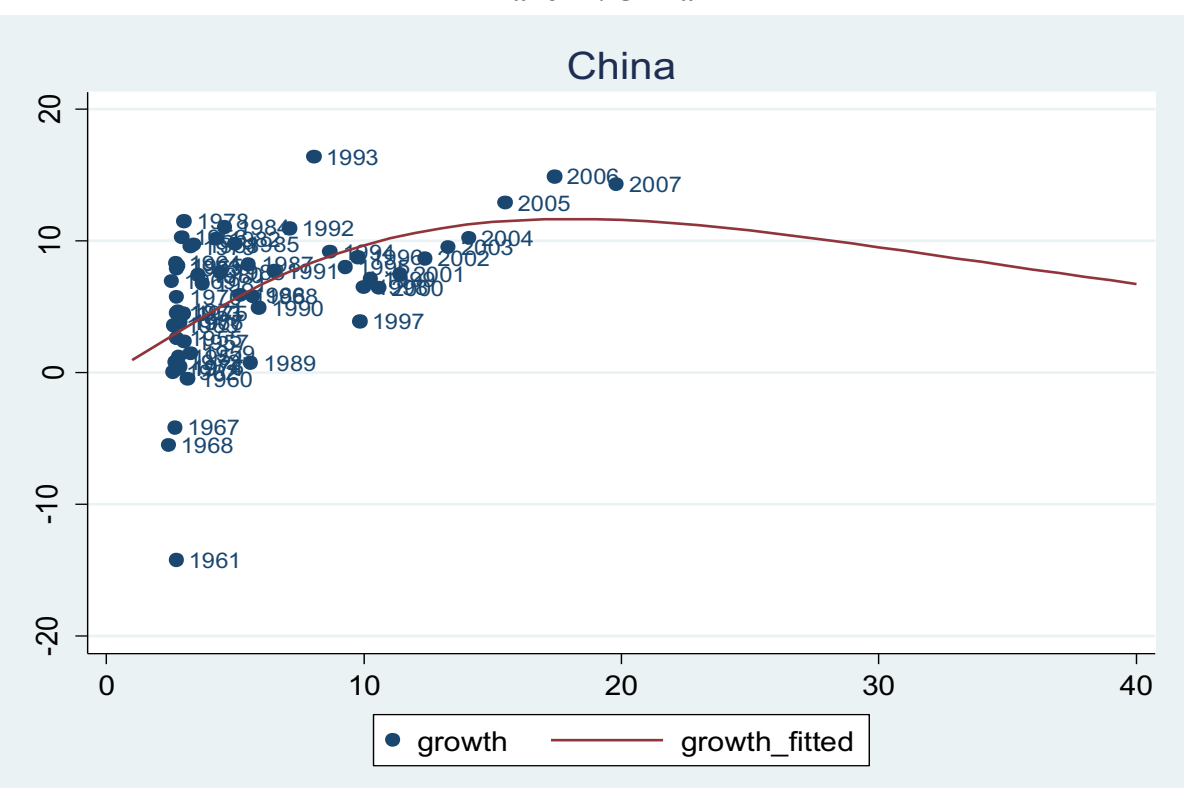

A slowdown does not prescribe a perpetual halt in the economic growth. In other words, it tells us that the economy tends to progress further. At the reflection point, Japan's income is $50 \%$ relative to that of the U.S. which undermines the reality to a certain extent as Japan undergoes a conspicuous growth phase at this stage. However, given that the Japanese economy stagnated at around 70\% of U.S.'s income in the past 40 years (except during the bubble period of the late 1980's), and its relative income may shrink even further due to a series of economic recessions and natural disasters, such as the strong tsunami shock in 2011, this estimate is deemed reasonable. South Korea, Taiwan, and Hong Kong are predicted to slow down at $62 \%, 51 \%$, and $67 \%$ respectively. 
China's reflection point is at around 36\%. This means that China's slowdown period may arrive earlier than other countries. Considering that the Japanese economy bottlenecked at around $70 \%$ of U.S.'s income even though its reflection point was $50 \%$, we may predict that the Chinese economy will sustain a high growth even though it reaches the reflection point, and will stay in a "warm" status for approximately additional $20 \%$ until it becomes 50 $60 \%$ relative to the U.S. This is unprecedented for there has been no large size economy which made such a rapid growth so far. However, in the current stage where China's per capita income is $19.8 \%$ of the U.S. and is expected to rise sharply, it is reasonable to identify a "cooling point" for its economy. Moreover, given that China's double digit growth may be partly due to the low price level, its growing inflation rate (5\% in the first quarter of 2011) coupled with the overall global price increase in raw materials may lead to an early deceleration for its rapid growth (Barboza, 2008).

\section{CONCLUSION}

This study examined the relationship between the size of a country and its "take-off" for economic development. We find that small countries are not necessarily efficient in taking off. However, most countries that experienced the economic upheavals and have been under accelerated growth for the past decades were relatively small in terms of land size and population. Specifically, economic growth appears to be quicker the smaller the landmass, the larger the potential workforce, and the higher the population density, controlled for capital markets maturity, corporate governance, economic openness, and human capital development. The cases of Japan, South Korea, and Taiwan are examined with implications for the future growth prospect of China.

Future research agenda can include providing prescriptions for extending the sustained high growth period. Readers may focus on examining policies that may lead to the successful completion of long jumps of currently developing countries. They can be spatial urban policies, as discussed in World Bank's World Development Report 2009. A closer investigation of past long jumpers in Group 1 economies may provide answers for better policy prescriptions toward on-going jumpers.

\section{AUTHOR'S NOTE}

Standard disclaimer rules apply and all errors are of our own.

\section{AUTHOR BIOGRAPHIES}

Choi is an assistant professor of finance at Ewha School of Business. Before he joined Ewha at 2010, he has taught at State University of New York at Binghamton. He received his degrees from Yonsei (B.A.), Harvard (M.A.), and Cornell University (Ph.D)

Oh is an assistant professor at Ewha Graduate School of International Studies. His research focuses on economic analysis of international development, geographic aspects of core-periphery problems, and political economy of international trade. He received his degrees from Yonsei (B.A.), Brown (M.A.) and Cornell University (Ph.D.). Prior to joining Ewha, he has taught at International University of Japan. (corresponding author)

Ko is a Ph.D. candidate at the University of California, Los Angeles. He received his B.A. from Yonsei University.

\section{ACKNOWLEDGEMENTS}

This work was supported by the National Research Foundation of Korea Grant funded by the Korean Government (NRF-2013S1A5A8022842).

\section{REFERENCES}

Alesina, A., Spolaore, E., 1997. On the number and size of nations. Quarterly Journal of Economics 112, 1027-1056

Alesina, A., Wacziarg, R., 1998. Openness, country size and government. Journal of Public Economics 69, 305-321.

Armstrong, H.W., Read, R., 1998. Trade and growth in small states: The impact of global trade liberalisation. World Economy 21, 563-585.

Barboza, D., 2008. Once sizzling, China's economy shows rapid sign of fizzling. The New York Times, p. B1. 7 November. 
Barro, R., Lee, J-W., 2012. A new data set of educational attainment in the world, 1950-2010. Journal of Development Economics, In press.

Brigulio, L., 1995. Small island developing states and their economic vulnerabilities. World Development 23, 1615-1632.

Chang, H.-J., 2002. Kicking away the ladder. U.K.: Cambridge University Press.

Djankov, S., La Porta, R., Lopez-de-Silanes, F., Shleifer, A., 2008. The law and economics of self-dealing. Journal of Financial Economics 88(3), 430-465.

Easterly, X., Kraay, X., 2000. Small states, small problems? Income, growth and volatility in small states. World Development 28, 2013-2027.

Eichengreen, B., Park, D., Shin, K., 2013. Growth slowdowns redux: New evidence on the middle-income trap. NBER Working paper 18673.

Kornai, J., 1992. The socialist system: The political economy of communism. New Jersey: Princeton University Press.

Krugman, P., 1991. Increasing returns and economic geography. Journal of Political Economy 99, 483-499.

Krugman, P., 1998. The role of geography in development. International Regional Science Review 22, 142-161.

La Porta, R., Lopez-de-Silanes, F., Shleifer, A., Vishny, R., 1998. Law and finance. Journal of Political Economy 106, 11131155.

Lucas, Robert E., 2009. Trade and the diffusion of the industrial revolution. American Economic Journal: Macroeconomics 1, 125.

Milner., X., Westaway, X., 1993. Country size and the medium-term growth process: Some cross-country evidence. World Development 21, 203-211.

Sachs, J., Warner, A., 1995. Economic reform and the process of global integration. Brookings Papers on Economic Activity, 1118

World Bank, 2009. World development report 2009: Reshaping economic geography. D.C.: World Bank. 